\title{
Groundwater Vulnerability from Sea Water Intrusion in Coastal Area Cilacap, Indonesia
}

\author{
Setyawan Purnama \\ Faculty of Geography, Universitas Gadjah Mada, Yogyakarta, Indonesia
}

Received: 2019-05-18 Accepted: 2019-07-29

Keywords: groundwater vulnerability, sea water intrusion, coastal city, Cilacap, Indonesia

Corespondent Email Igiwan@ugm.ac.id

\begin{abstract}
The important issue relating to water resources is sea water intrusion (SWI) phenomena. Nowadays, the phenomena has become serious problem in the urban coastal area. Groundwater as main sources for domestic usage cannot be used again because of its salinity.Cilacap as one of urban coastal area also face the problem. In 1977 SWIwas detectedand experienced significant developmentsin 1996, This research was conducted to: (1) analyze agroundwater vulnerability to the SWI; (2) determine adistance and adepth theinterface; and (3) analyze relationship of the groundwater vulnerability to the interface depth.It was performed an analysis of the groundwater vulnerability to the SWI using the method of GALDIT, whereas the distance and depth of the interface was determined using the method of DupuitGhyben-Herzberg. The linkage analysis of the groundwater vulnerability to the depth of the actual interface was conducted by quantitative descriptively.The results showed that the distance from the shoreline was the most determined factor of the groundwater vulnerability to the SWI, the closer to the shoreline the more swallow the depth of the interface. It existed the relevance between the vulnerability level of groundwater to the SWI with the depth of actual interface. The regions with low level of vulnerability had deep interface depth, whereas the regions with moderate level of vulnerability had swallow interface depth. Nevertheless, the SWI has not yet affected the groundwater in people wells because of its depth that was not yet exceeded of $25 \mathrm{~m}$.so that this depth can be used as a reference in digging wells in the research area++
\end{abstract}

(9) 2019 by the authors. This article is an open access article distributed under the terms and conditions of the Creative

Commons Attribution(CC BY NC) licensehttps://creativecommons.org/licenses/by-nc/4.0

\section{Introduction}

Coastal is a contact area between land and sea. Towards the land covers parts of the land, both dry and submerged in water, which are still influenced by the characteristics of the sea such as tides, sea breezes, and SWI, while towards the sea covers the part of the sea which is still influenced by natural processes. Because of this location, coastal areas are vulnerable to various problems such as SWI and tidal flooding.

Partly citiesin Java, Indonesia are located incoastal area, such as:Jakarta, Cirebon, Pekalongan, Semarang, and Surabaya are some of cities located on the northern coast of Java, whereas Cilacap is located on the southern one of Java Island. In general, coastal zone often face intensive pressures for development (Gwalema, 2011). Beside it, urban areas in the coastal area have faster rate of growth than the rural ones, marked by higher level of population growth and the expansion of residential areas.A greater growing number of people needs more facilities and infrastructure, one of them is water resources availability. It would affect to the greater number of groundwater extraction, whereas in another side it would be decreased the groundwater inflow because of the larger open land used for recharge area was converted into residential area (Tillman \& Leake, 2010; Fenta \& Kifle, 2014; Waikar \& Nilawar, 2014).

The decreased number of groundwater would effect to the decreased number of water pressure that could cause penetration of saline water from sea into the mainland (Pousa, et al., 2007; Marandi \& Vallner, 2010). This phenomenon is called sea water intrusion (SWI), whereas border between freshwater and saline water is called interface (Young Kim, Suk Park, \& Pyo Kim, 2009; Basack, Bhattacharya, Sahana, \& Maity, 2010; Rotzoll, et al., 2010). Beside that, recently SWI was also driven by future sea level rise which result to the increase of the fresh water front forward move (Rahmawati, Vullaume, \& Purnama, 2013). It could be said that the SWI is problematic issue in the cities located on the coastal regions, because it could make quality changes of groundwater that could not be use more as drinking water resource (Obikoya, 2010; Dayal \& Chauhan, 2010).

Some researchresults showed that it has been detected an interface in Cilacap City. It turned out over time the depth of interface in some places of the city was changed. In 1996 it was found the existence of SWI in some places that were not detected with it in 1977 (Simoen, Darmanto, \& Darsomartoyo, 1977; Purnama, Perkembangan intrusi air laut di Kota Administratif Cilacap., 1996). Nevertheless, some places with interface in 1977 and 1996 were not detected anymore with it in 2013 (Purnama, et al., 2013). Related to this 
problem, it has been continued the research of SWI in the coastal area of Cilacap to get actual information about the effects of distance from the shoreline to the depth of interface in the researcharea.

Base on the background, the objectives of the research are (1) analyze the groundwater vulnerability to the SWI in the research area, (2) determine the distance and the depth of the interface in the research area, and (3) analyze the relationship of the groundwater vulnerability to the interface depth.

\section{The Methods}

To find out the relationship between groundwater vulnerability fromSWI and distance from shoreline and interface depth two method were used, namely GALDIT method and Dupuit Ghyben-Herzberg principle With the GALDIT, it can be seen the environmental condition of a place related to its vulnerability including the distance from the shore line, whereas with the Dupuit Ghyben-Herzberg, the depth of the interface can be known at a certain distance on the shore line. The GALDIT method has been successfully uses to asses groundwater vulnerability from SWI in the Portuguese aquifer system of Monte Gardo (LoboFerreira, Chachadi, Diamantino, \& Henriques, 2005) and the Bardez aquifer in Goa India (Chachadi \& LoboFerreira, 2005).

\section{Determination of Groundwater Vulnerability}

It was conducted a research using GALDIT method to get the information about groundwater vulnerability fromSWI. GALDIT stands for parameters that can cause sea water intrusion. $G$ is defined as groundwater occurrence, $\mathrm{A}$ is defined as aquifer hydraulic conductivity, $\mathrm{L}$ is defined as level of groundwater above mean sea level, D is distance from the shore, I as impact of existing status of SWI and T is thickness of aquifer being mapped (Chachadi \& Lobo-Ferreira, 2005).

The basic principle of this method was determination of vulnerability based on numerical system in weight and rating. The weight was determined based on the significance of parameter influence to SWI, whereas rating was specified based on the significancy of variable effect of each parameter to the SWI. Weight and rating of each GALDIT parameter and variable is shown in Tables 1 and 2.

\section{Determination of Distance and Interface Depth}

Theoritically, the groundwater flow in the coastal aquifer could be explained through the combination of Dupuit equation and Ghyben-Herzberg principle such as the following (Fetter, 2001) :

$\mathrm{z}=\mathrm{Gq} / \mathrm{K}+\sqrt{ }(2 \mathrm{Gqx} / \mathrm{K})$

by $q$ is the specific discharge of groundwater per unit of wide in $\mathrm{m} 3 /$ day $/ \mathrm{m}$, $\mathrm{x}$ is shoreline distance to the point of the determined land and $\mathrm{K}$ is hydraulic conductivity that determined by Morris and Johnson criteria (Todd \& Mays, 2005). The specific discharge of groundwater could be calculated by using the method of Darcy (Rushton, 2003; Davie, 2008):

$\mathrm{q}=\mathrm{K} . \mathrm{A} \cdot \mathrm{dh} / \mathrm{dl}$

by $\mathrm{dh} / \mathrm{dl}$ is hydraulic gradient.

The heigh of freatic level from sea water level in each distance of $\mathrm{x}$ and the depth of $\mathrm{z}$ interface could be determined using the following equation (Fetter, 2001) : $\mathrm{h}=\sqrt{ }(2 \mathrm{qx} / \mathrm{GK})$

To validate the calculated results, it could be conducted a measurement of electrical conductance in the observed well. If the electrical conductance is less than $1500 \mu \mathrm{mhos} / \mathrm{cm}$, it could be said that the observed well is not yet influenced by the saline water. Likewise, if the level of chloride is less than $150 \mathrm{mg} / \mathrm{l}$, it could be said for the same condition of the observed well.

\section{Result and Discussion}

Groundwater Vulnerability

As explained before, therewere six types of parameters used to calculate the index of GALDIT i.e. aquifer hydraulic conductivity, height of groundwater level, distance from the shoreline, ratio of $\mathrm{Cl}-/$ [HCO3$+\mathrm{CO} 32-]$, and thickness of aquifer. Because of the different influence of each parameters in saline water intrusion, the weight was also different. For the aquifer type the weight was 1 , the aquifer hydraulic conductivity was 3, height of groundwater level was 4 , distance from the shore was 4 , the ratio of $\mathrm{Cl}-/[\mathrm{HCO} 3-+\mathrm{CO} 32-]$ was 1 , and for the aquifer thickness was 2 .

Result determinant of rating of each parameter indicated that based on the composition of rock layering of the data drilling, there was only one types of aquifers in the research area that is unconfined aquifer, so that the same value of the rating was 7.5. Related to the aquifer constituent rocks, all of them have sand textured so that the aquifer hydraulic conductivity was also 7.5 .

It was quite varied for the height of groundwater level in the sea level. Nevertheless, almost all had categories of more than 2 meters of mean sea level, so that it valued of 2.5. Only one observed wells which had the groundwater level between 1.5-2 m of mean sea level and 5 in value.

It was estimated that the distance from the shoreline was dominant parameter in determining the groundwater vulnerability in the research area because its value was quite varied, and it was similar for the ratings. The results of rating determination showed that the parameter of distance from the shoreline varied from 2.5 to 10 .

Giving attention to the ratio value of $\mathrm{Cl}-/[\mathrm{HCO} 3-$ + CO32-], it was known that the groundwater in observed wells had value between 0.13 to 0.33 . Based on the rating of GALDIT index, the value range was entered in one category and was valued by 2.5 . It was also existed for the parameters of the aquifer thickness that ranged from 11.39 to $17.55 \mathrm{~m}$. Based on the ratings 
Table 1. Rating forparameter aquifer type

\begin{tabular}{llll}
\hline Indicator & Weight & Indicator Variable & Vulnerability Rating \\
\hline Aquifer Type & 1 & Confined Aquifer & 10 \\
& & Unconfined Aquifer & 7.5 \\
& & Semi-Confined Aquifer & 5 \\
& & Bounded Aquifer & 2.5 \\
\hline
\end{tabular}

Source : Chachadi A.G. \& Lobo-Ferreira, J.P. 2005

Table2. Ratingsfor parameteraquifer hydraulic conductivity, height of groundwater level above sea level, distance from the shoreline, ratio of $\mathrm{Cl}-/[\mathrm{HCO} 3-+\mathrm{CO} 32-]$, and thickness of aquifer

\begin{tabular}{|c|c|c|c|c|}
\hline \multirow[b]{2}{*}{ Indicator } & \multirow[b]{2}{*}{ Weights } & \multicolumn{2}{|c|}{ Indicator Variable } & \multirow[b]{2}{*}{ Vulnerability } \\
\hline & & & & \\
\hline & & Class & Range & Rating \\
\hline \multirow[t]{4}{*}{ Aquifer hydraulic conductivity (m/day) } & 3 & High & $>40$ & 10 \\
\hline & & Medium & $10-40$ & 7.5 \\
\hline & & Low & $5-10$ & 5 \\
\hline & & Very low & $<5$ & 2.5 \\
\hline \multirow{4}{*}{$\begin{array}{l}\text { Height of groundwater level above sea } \\
\text { level }(\mathrm{m})\end{array}$} & 4 & High & $<1$ & 10 \\
\hline & & Medium & $1-1.5$ & 7.5 \\
\hline & & Low & $1.5-2$ & 5 \\
\hline & & Very low & $>2$ & 2.5 \\
\hline \multirow[t]{4}{*}{ Distance from the shoreline $(\mathrm{m})$} & 4 & Very small & $<500$ & 10 \\
\hline & & Small & $500-750$ & 7.5 \\
\hline & & Medium & $750-1000$ & 5 \\
\hline & & Far & $>1000$ & 2.5 \\
\hline \multirow[t]{4}{*}{ Ratio of Cl-/[HCO3-+CO32-] (epm) } & 1 & High & $>2$ & 10 \\
\hline & & Medium & $1.5-2$ & 7.5 \\
\hline & & Low & $1-1.5$ & 5 \\
\hline & & Very low & $<1$ & 2.5 \\
\hline \multirow[t]{4}{*}{ Thickness of aquifer (m) } & 2 & Large & $>10$ & 10 \\
\hline & & Medium & $7.5-10$ & 7.5 \\
\hline & & Small & $5-7.5$ & 5 \\
\hline & & Very small & $<5$ & 2.5 \\
\hline
\end{tabular}

Source : Chachadi A.G. \& Lobo-Ferreira, J.P. 2005

Table3. GALDIT vulnerability classes

\begin{tabular}{ll}
\hline Index Range of GALDIT & Vulnerability Classes \\
\hline$>7.5$ & High vulnerability \\
$5-7.5$ & Moderate vulnerability \\
$<5$ & Low vulnerability \\
\hline
\end{tabular}

Source : (Chachadi \& Lobo-Ferreira, 2005)

of GALDIT index, the range value was entered in one category thickness level with the value of 10 .

Furthermore, based on the ratings of each parameter it could be calculated the GALDIT index for each observed well. The calculations showed that there were eight observed wells with the GALDIT index of 4.8, two observed wells with the GALDIT index of 5.5, and seven observed wells with the GALDIT index of 6.8. Viewed from the vulnerability level, eight observed wells were belonged to the level of low vulnerability and nine observed wells were belonged to the moderate vulnerability. It is regarded from the spreading, generally the observed wells with the moderate vulnerability level were located at the closer distance from the shoreline, whereas the observed wells with the low level of vulnerability were located further away from the shoreline. Based on this data (Table 4), it could be created a Groundwater Vulnerability Map of saline water intrusion in the research area as shown in Figure 1. 


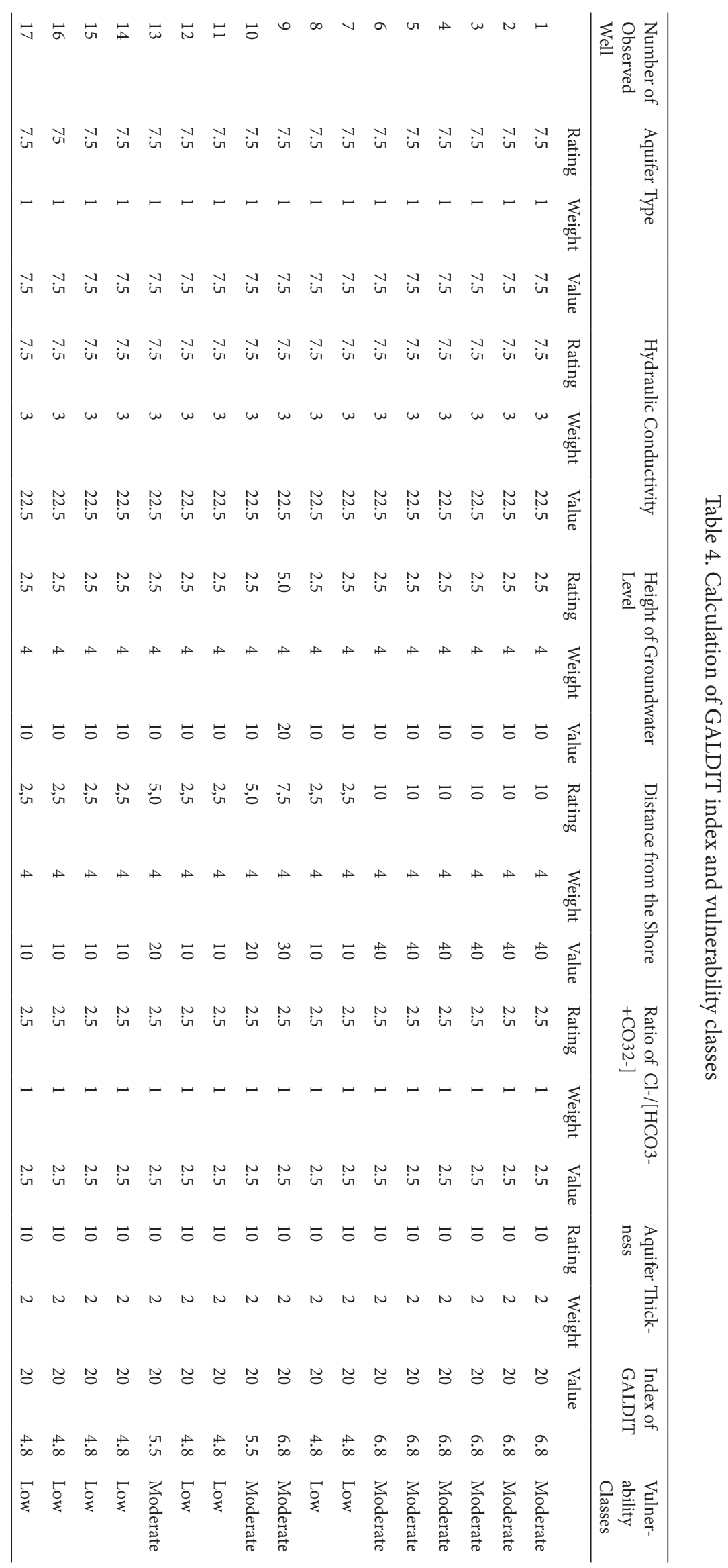




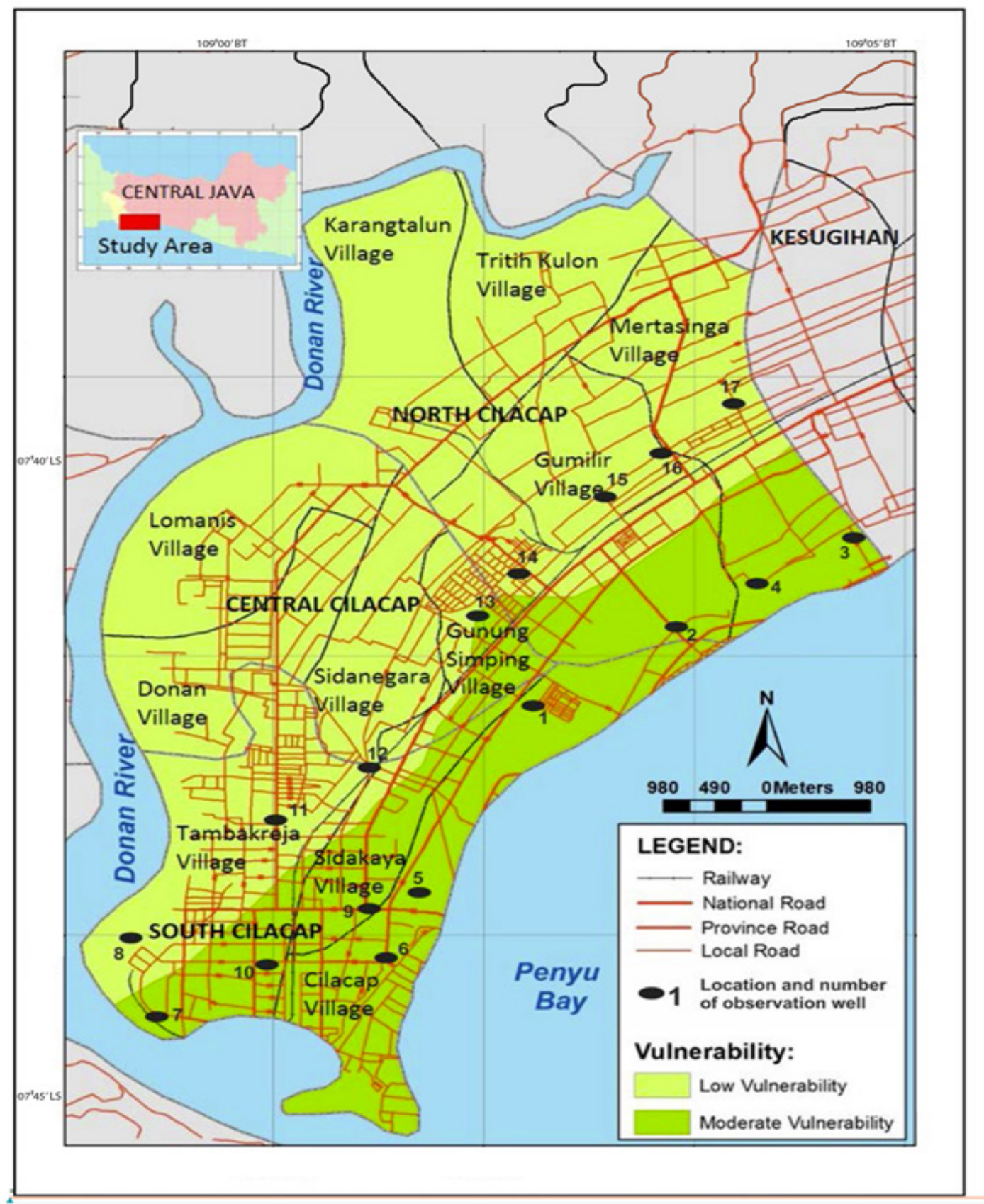

Figure 1. Groundwater Vulnerability Map fromSWI in the research area

Regarding to the Groundwater Vulnerability Map of saline water intrusion that is shown in Figure 1, it could be said that the distance from the shoreline was the most determined factor of the groundwater vulnerability to the saline water intrusion in Cilacap coastal area. The closer area to the shoreline has a higher vulnerability to the saline water intrusion than the farther area.

\section{Calculation of Specific Discharge}

In this research, it was conducted the calculation of specific discharge at all observed wells in accordance with the path of groundwater flow in the flownet. Such as explained in research methods, the equations used in the calculation was the general equation of groundwater

\section{flow from Darcy.}

In accordance with this equation, calculation of groundwater specific discharge needed some data i.e. aquifer hydraulic conductivity, aquifer cross-sectional area, and hydraulic gradient. The value of aquifer hydraulic conductivity is determined based on drilling data, which are located closest to the observed wells. In the area of research there are three data drillings i.e. villages of Cilacap, Sidanegara, and Tambakreja. Considering to the constituent material of the aquifer, the three sites of drilling are composed of sand with varied colors i.e. brown and yellow sand at the top, and black and gray sand on the bottom. Based on the Morris and Johnson criteria (Todd \& Mays, 2005), the hydraulic conductivity value of sand is $12 \mathrm{~m}$ /day. 


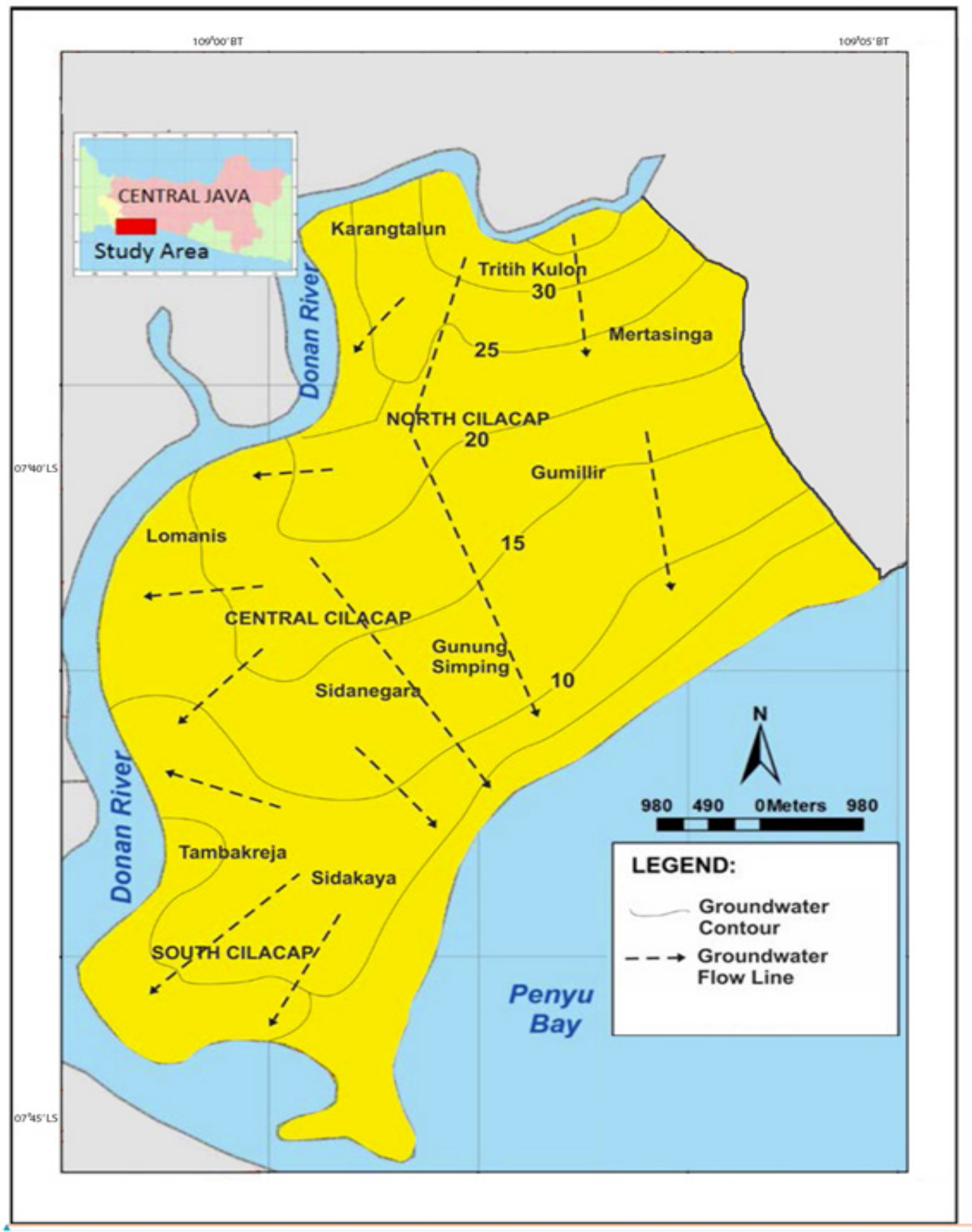

Figure 2. Groundwater flownet

The wide of aquifer section determined by multiplying the aquifer thickness with the width of the groundwater flow paths located in the observed wells. Based on data from the three drilling data, it is varied the aquifer thickness in these three places. Cilacap village has a aquifer thickness of $18 \mathrm{~m}$, Sidanegara village has $14 \mathrm{~m}$, while Tambakreja village has 17 $\mathrm{m}$. Based on data from these tree sites, it could be determined interpolately the thickness of the aquifer at each observed well. For aquifer width as a specific discharge calculation, the value is determined by $1 \mathrm{~m}$.
Hydraulic gradient calculation is based on data from groundwater flownet (Figure 2). Regarding to the height of equipotential lines and the adjacent line distance, it could be determined the hydraulic gradient. The completely calculating result of the groundwater is shown in Table 5.

Table 5 showed that the smallest value of groundwater specific discharge could be found in Tegalreja village $0.18 \mathrm{~m} 3 /$ day, whereas the largest value of groundwater specific discharge is existed in Mertasinga village $1.60 \mathrm{~m} 3 /$ day. 
Table 5. Calculation of specific discharge in each section of observed well

\begin{tabular}{|c|c|c|c|c|c|c|}
\hline \multirow{2}{*}{$\begin{array}{l}\text { Number of Ob- } \\
\text { served Well }\end{array}$} & \multirow{2}{*}{$\begin{array}{l}\text { Hydraulic Con- } \\
\text { ductivity }(\mathrm{K}), \mathrm{m} / \\
\text { hari }\end{array}$} & \multicolumn{2}{|c|}{ Wide of Aquifer Section (A), m2 } & & \multirow{2}{*}{$\begin{array}{l}\text { Hydraulic Gradi- } \\
\text { ent }(\mathrm{dh} / \mathrm{dl}), \mathrm{m}\end{array}$} & \multirow{2}{*}{$\begin{array}{l}\text { Specific Discharge } \\
\text { (q), m3/hari }\end{array}$} \\
\hline & & $\begin{array}{l}\text { Aquifer Thickness } \\
\text { (D), m }\end{array}$ & $\begin{array}{l}\text { Aquifer Width } \\
\text { (L), m }\end{array}$ & & & \\
\hline 1 & 12 & 13.15 & & 1 & 0.0083 & 1.31 \\
\hline 2 & 12 & 13.25 & & 1 & 0.0064 & 1.02 \\
\hline 3 & 12 & 14.00 & & 1 & 0.0095 & 1.60 \\
\hline 4 & 12 & 13.50 & & 1 & 0.0078 & 1.26 \\
\hline 5 & 12 & 17.30 & & 1 & 0.0076 & 1.58 \\
\hline 6 & 12 & 16.50 & & 1 & 0.0014 & 0.28 \\
\hline 7 & 12 & 16.80 & & 1 & 0.0036 & 0.73 \\
\hline 8 & 12 & 15.49 & & 1 & 0.0018 & 0.33 \\
\hline 9 & 12 & 17.55 & & 1 & 0.0019 & 0.40 \\
\hline 10 & 12 & 16.87 & & 1 & 0.0027 & 0.55 \\
\hline 11 & 12 & 16.57 & & 1 & 0.0009 & 0.18 \\
\hline 12 & 12 & 12.79 & & 1 & 0.0069 & 1.06 \\
\hline 13 & 12 & 12.72 & & 1 & 0.0081 & 1.24 \\
\hline 14 & 12 & 13.38 & & 1 & 0.0035 & 0.56 \\
\hline 15 & 12 & 13.34 & & 1 & 0.0070 & 1.12 \\
\hline 16 & 12 & 12.30 & & 1 & 0.0071 & 1.05 \\
\hline 17 & 12 & 11.39 & & 1 & 0.0040 & 0.55 \\
\hline
\end{tabular}

Table 6. Height calculation of groundwater level from mean sea level

\begin{tabular}{|c|c|c|c|c|c|c|}
\hline $\begin{array}{l}\text { Number of Ob- } \\
\text { served Well }\end{array}$ & $\begin{array}{l}\text { Specific Discharge } \\
\text { (q), m3/hari }\end{array}$ & $\begin{array}{l}\text { Distance from } \\
\text { Shore }(\mathrm{x}), \mathrm{m}\end{array}$ & $\begin{array}{l}\rho f / \rho s-\rho f \\
\text { (G) }\end{array}$ & & $\begin{array}{l}\text { Hydraulic Con- } \\
\text { ductivity }(\mathrm{K}), \mathrm{m} / \\
\text { hari }\end{array}$ & $\begin{array}{l}\text { Height of } \\
\text { Groundwater } \\
\text { Level from Mean } \\
\text { Sea Level (h), m }\end{array}$ \\
\hline 1. & 1.31 & 350 & & 40 & 12 & 1.38 \\
\hline 2. & 1.02 & 350 & & 40 & 12 & 1.21 \\
\hline 3. & 1.60 & 400 & & 40 & 12 & 1.63 \\
\hline 4. & 1.26 & 400 & & 40 & 12 & 1.45 \\
\hline 5 & 1.58 & 300 & & 40 & 12 & 1.40 \\
\hline 6. & 0.28 & 300 & & 40 & 12 & 0.59 \\
\hline 7. & 0.73 & 1900 & & 40 & 12 & 2.40 \\
\hline 8. & 0.33 & 2500 & & 40 & 12 & 1.85 \\
\hline 9. & 0.40 & 500 & & 40 & 12 & 0.91 \\
\hline 10. & 0.55 & 750 & & 40 & 12 & 1.72 \\
\hline 11. & 0.18 & 1500 & & 40 & 12 & 1.06 \\
\hline 12. & 1.06 & 1100 & & 40 & 12 & 2.20 \\
\hline 13. & 1.24 & 750 & & 40 & 12 & 1.97 \\
\hline 14. & 0.56 & 1850 & & 40 & 12 & 2.08 \\
\hline 15. & 1.12 & 2000 & & 40 & 12 & 3.05 \\
\hline 16. & 1.05 & 1500 & & 40 & 12 & 2.56 \\
\hline 17. & 0.55 & 1750 & & 40 & 12 & 2.00 \\
\hline
\end{tabular}


Indonesian Journal of Geography, Vol. 51 No. 2, August 2019 : 206 - 216

\begin{tabular}{|c|c|c|c|c|c|}
\hline $\begin{array}{l}\text { Number of Ob- } \\
\text { served Well }\end{array}$ & $\begin{array}{l}\text { Groundwater } \\
\text { Specific Discharge } \\
\text { (q), m3/hari }\end{array}$ & $\begin{array}{l}\text { Distance from the } \\
\text { Shoreline }(\mathrm{x}), \mathrm{m}\end{array}$ & $\mathrm{Gq} / \mathrm{K}, \mathrm{m}$ & $\sqrt{2} \mathrm{Gqx} / \mathrm{K}, \mathrm{m}$ & $\mathrm{z}, \mathrm{m}$ \\
\hline 1. & 1.31 & 350 & 4.37 & 55.29 & 59.66 \\
\hline 2. & 1.02 & 350 & 3.40 & 48.78 & 52.18 \\
\hline 3. & 1.60 & 400 & 5.33 & 65.32 & 70.65 \\
\hline 4. & 1.26 & 400 & 4.20 & 57.97 & 62.17 \\
\hline 5 & 1.58 & 300 & 5.27 & 56.21 & 61.48 \\
\hline 6. & 0.28 & 300 & 0.93 & 23.66 & 24.59 \\
\hline 7. & 0.73 & 1900 & 2.43 & 96.16 & 98.59 \\
\hline 8. & 0.33 & 2500 & 1.10 & 74.16 & 75.26 \\
\hline 9. & 0.40 & 500 & 1.33 & 36.51 & 37.84 \\
\hline 10. & 0.55 & 750 & 1.83 & 52.44 & 54.27 \\
\hline 11. & 0.18 & 1500 & 0.60 & 42.43 & 43.03 \\
\hline 12. & 1.06 & 1100 & 3.53 & 88.17 & 91.70 \\
\hline 13. & 1.24 & 750 & 4.13 & 78.74 & 82.87 \\
\hline 14. & 0.56 & 1850 & 1.87 & 83.11 & 84.98 \\
\hline 15. & 1.12 & 2000 & 3.73 & 122.20 & 125.93 \\
\hline 16. & 1.05 & 1500 & 3.50 & 102.47 & 105.97 \\
\hline 17. & 0.55 & 1750 & 1.83 & 80.10 & 81.93 \\
\hline
\end{tabular}

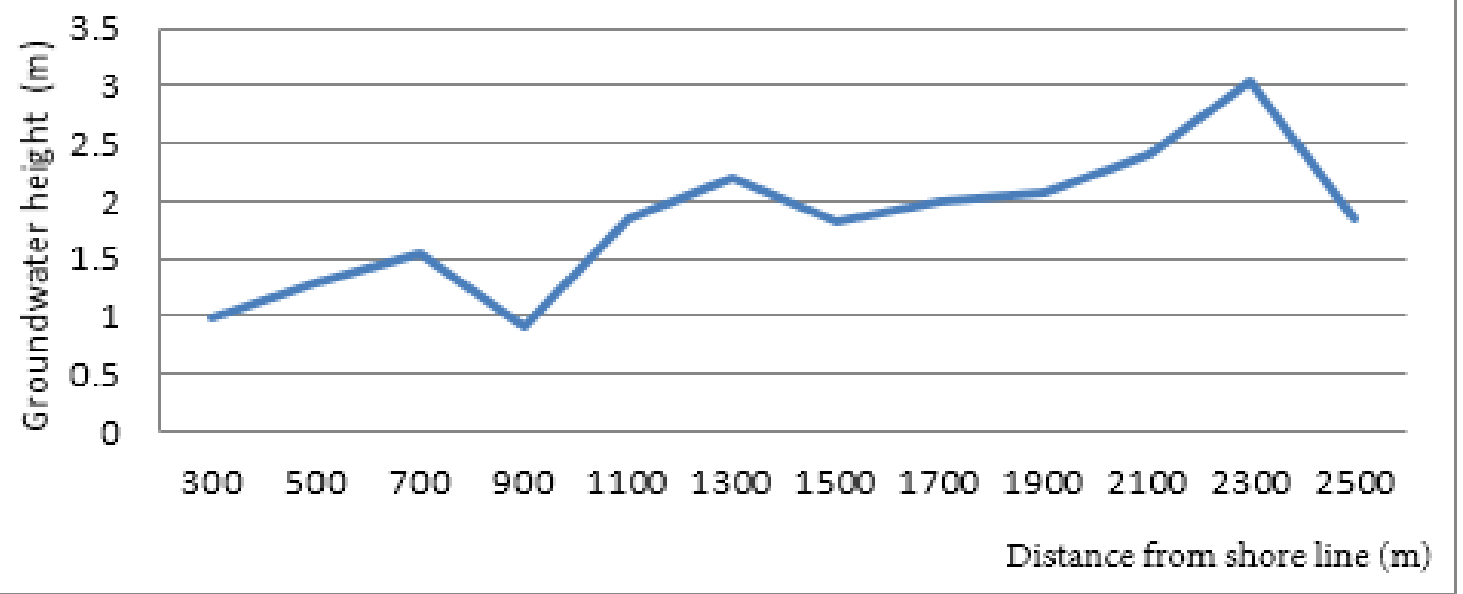

Figure 3. Relationship between distance from shore line and groundwater height

Height Calculation of Groundwater Level from Mean Sea Level

The height of groundwater level from mean sea level is determined by the parameters i.e. specific discharge of groundwater, distance from shoreline, the density of freshwater and saline water, and the aquifer hydraulic conductivity. The groundwater specific discharge of each observed wells is based on the calculating results in Table 5, freshwater density that is appropriate with the Law Ghyben-Herzberg is determined by $1.000 \mathrm{~g} /$ $\mathrm{cm} 3$, whereas the density of saline water is determined by $1.025 \mathrm{~g} / \mathrm{cm} 3$ (Todd \& Mays, 2005). The calculating results could be regarded in Table 6 .

Considering to Table 6, the height of groundwater level from saline water level in the research area was ranged from 0.59 to $3.05 \mathrm{~m}$. The groundwater level with the height of $0.59 \mathrm{~m}$ was founded southern Cilacap village, whereas the groundwater level with the height of $3.05 \mathrm{~m}$ is existed in Gumilir village. It could be said that the farther distance from the shoreline, the higher the groundwater level. This statement is proved by graphic that showed in Figure 3., 


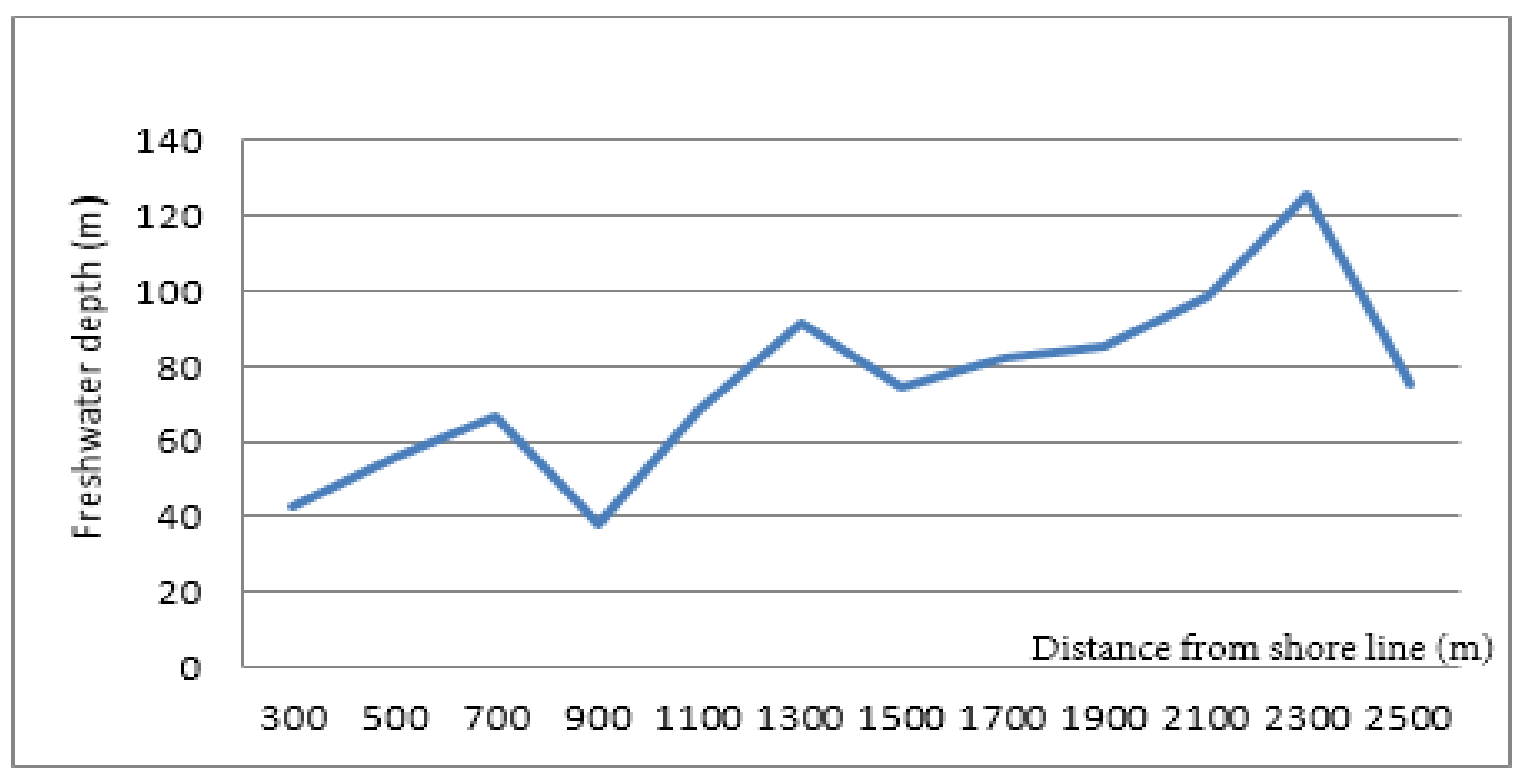

Figure 4. Relationship between distance from shore line and freshwater depth

\section{Calculation of Freshwater Depth from Sea Level}

The freshwater depth from saline water level is also determined by groundwater specific discharge, distance from the shoreline, density of freshwater and saline water, and aquifer hydraulic conductivity. The calculating results showed that the region of South Cilacap located $300 \mathrm{~m}$ from the shoreline, had the most shallow groundwater depth, $24.59 \mathrm{~m}$, whereas the region of Gumilir located $2000 \mathrm{~m}$ from the shoreline had the largest groundwater depth, $125.93 \mathrm{~m}$. This showed the tendency that the farther distance from the shoreline, the greater the depth of interface would be, and otherwise the closer distance from the shoreline, the swallower the depth of interface (Figure 4). The completely results related to the calculation of groundwater depth from sea water level could be regarded in Table 7.

\section{Vulnerability Relationship to SWI with Interface} Depth

The results showed that in the research area had been detected interface with varied depths, ranging from $26.68 \mathrm{~m}$ in South Cilacap to $129.74 \mathrm{~m}$ in Gumilir. There is a tendency that the closer to the shoreline, the more shallow the depth of interface and the farther distance from the beach the greater the depth of interface.

Considering to Table 8, it showed that there was a relationship between the level of groundwater vulnerability to the SWI with the actual depth of interface. In the regions with low vulnerability level, generally have a great depth of interface. Conversely, regions with moderate vulnerability level generally have a shallow depth of interface (Figure 5). Nevertheless, giving attention to the value of electrical conductance and chloride concentration could be said that the SWI had not affected to the groundwater in the wells of the people. This could be understood because of the community well had the depths that was not greater than $25 \mathrm{~m}$. It had to be maintained, which mean that do not let the people to make wells with the greater depth than the interface depth on the territory. If there is well with the greater depth than the interface depth, it would be happened an upconing, a process of saline water entrance to the well that would be so difficult to be recovered.

Although in general the interface depth has not affected the groundwater in the observed wells, there was a quite interesting phenomenon in the observed wells located in TegalKamulyan which had the distance of $500 \mathrm{~m}$ from the shoreline. The interface depth in the observed wells was only $39.2 \mathrm{~m}$ from the ground. If this phenomenon was associated with the groundwater specific discharge in the area, it would be seen a dangerous phenomenon. Compared with other areas of research, the groundwater specific discharge in the area was low, that was $0.40 \mathrm{~m} 3 /$ day. Whereas Tegal Kamulyan was an area with the relatively high density which also mean having high enough groundwater level. Therefore, this area needed more attention related to the danger of SWI.... This phenomenon also occurs in Ternate City, North Maluku Province, Indonesia (Achmad, Hadi, \& Purnama, 2016). The condition of rocks aquifer in the northern part of Ternate Island causes susceptibility to SWI. The contact limit for groundwater with sea water averages between 12-15 $\mathrm{m}$. Drilling of wells in coastal areas should not exceed $10 \mathrm{~m}$. If the extraction of groundwater is carried out uncontrollably or drilling is carried out too deeply, there will be infiltration of seawater into the body of groundwater. Cases of deep well drilling that took place in Takome Village were a real example that the hydrological conditions of the northern part of Ternate Island were very vulnerable to SWI. 
Indonesian Journal of Geography, Vol. 51 No. 2, August 2019 : 206 - 216

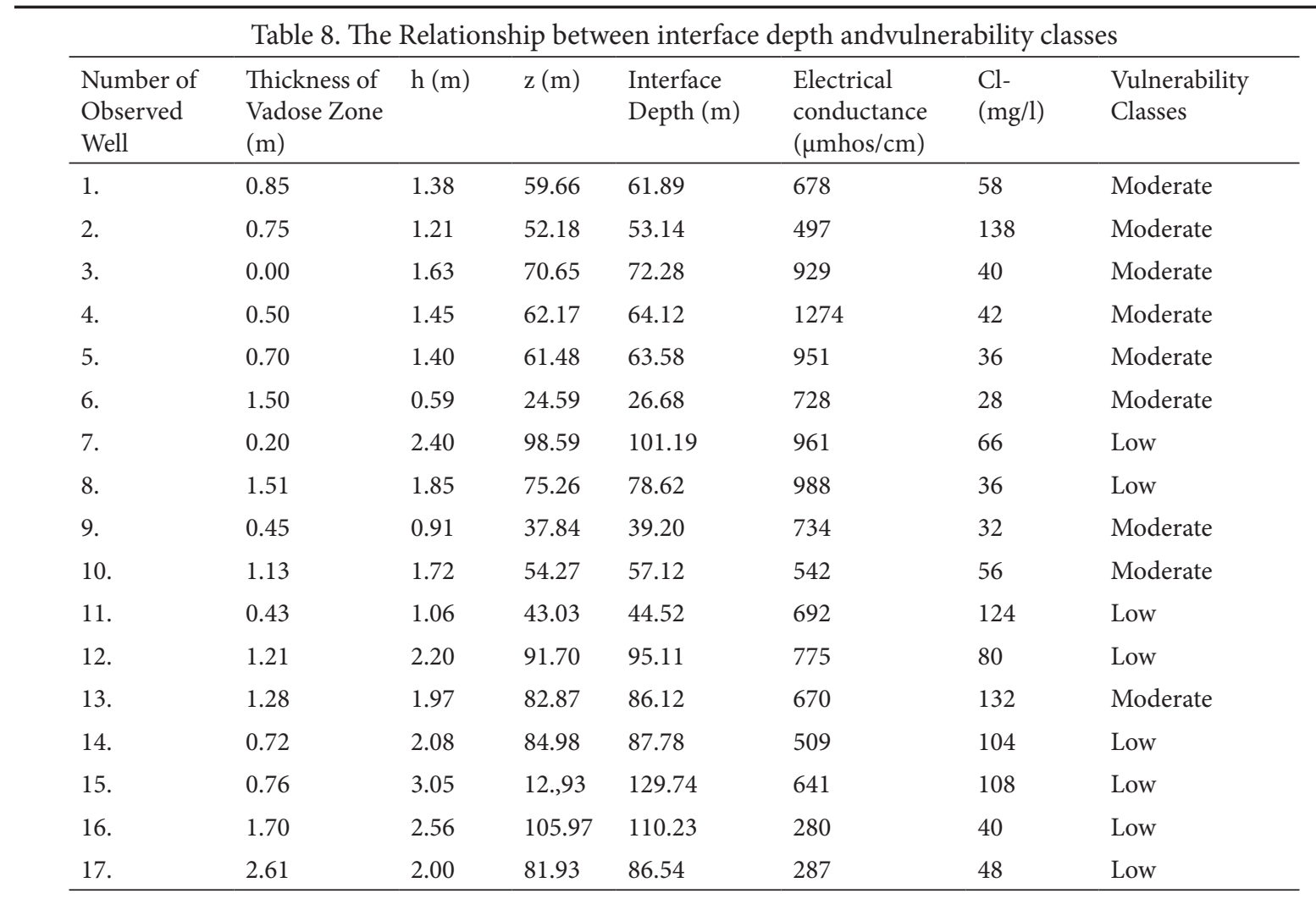

Source : calculation result

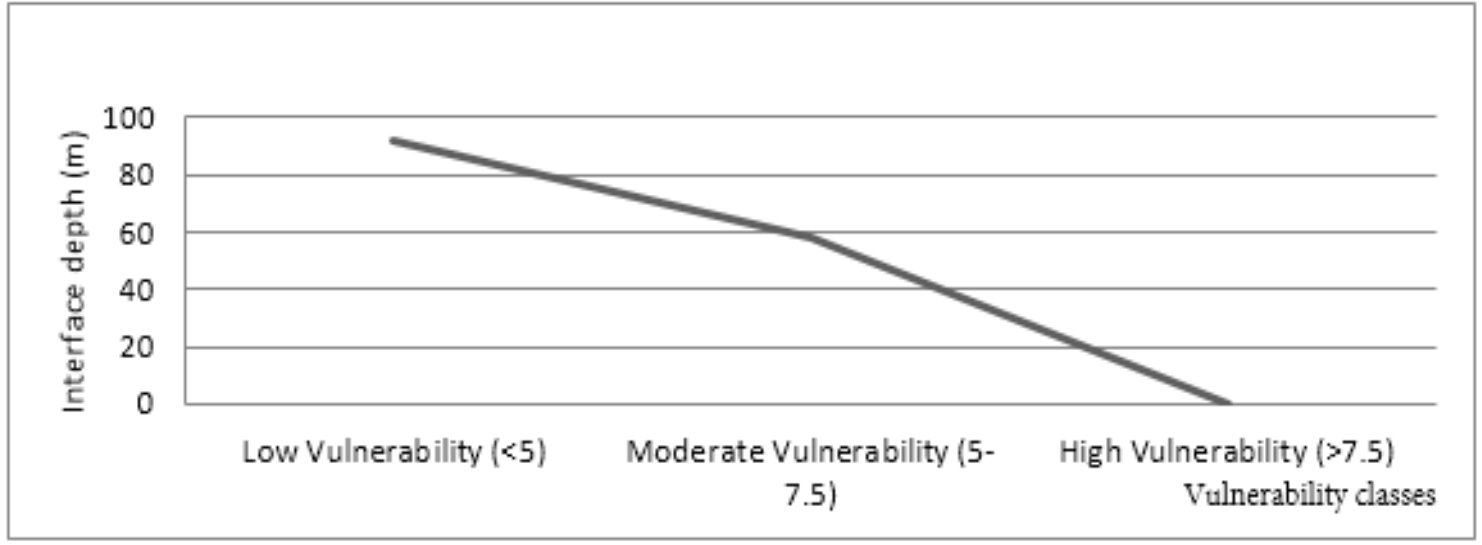

Figure5. Relationship between vulnerability classes and interface depth

\section{Conclusion}

The analysis results using method of GALDIT indicated that the distance from the shoreline was the most determined factor of the groundwater vulnerability to the SWI in the coastal area of Cilacap. It mean that the area which located closer to the shoreline had a higher vulnerability to the SWI compared with the area which located farther from the shoreline.The analysis results of SWI using a combination of Dupuit equations and Ghyben-Herzberg principles showed that the closer to the shoreline $(300 \mathrm{~m})$, the more shallow the interface depths $(24.59 \mathrm{~m})$.
There was a link between the level of groundwater vulnerability from the SWI with the depth of actual interface. Regions with low vulnerability level had a great depth of interface $(129.74 \mathrm{~m})$, whereas the regions with moderate vulnerability level had a shallow depth of interface $(39.20 \mathrm{~m})$. Nevertheless, the SWI had not affected to the groundwater in the community wells because of the depth was not exceeded of $25 \mathrm{~m}$. Base in this condition, this depth $(25 \mathrm{~m})$ can be used as a reference in digging wells in the research area 


\section{Acknowledgement}

We would like to acknowledge Faculty of Geography Universitas Gadjah Mada for the research funding and also to the reviewers who give their advices on this paper.

\section{References}

Achmad, R., Hadi, M., \& Purnama, S. (2016). Vulnerability of sea water intrusion in Northern Coastal of Ternate Island. J. Manusia dan Lingkungan, 23(2), 163-168.

Basack, S., Bhattacharya, A., Sahana, C., \& Maity, P. (2010). A study on saline water intrusion and fresh water recharge relevant to coastal environment. 3(5), 80-90.

Chachadi, A., \& Lobo-Ferreira, J. (2005). Assessing aquifer vulnerability to sea water intrusion using GALDIT Method: Part 2-GALDIT Indicators Description. The Fourth Inter-Celtic Colloquium in Hydrology and Management of Water Resources. Guimaraes, Portugal.

Davie, T. (2008). Fundamentals of Hydrology. London: Routledge, Taylor \& Francis Group.

Dayal, B., \& Chauhan, R. (2010). Recharge of saline water aquifers with rain water and its impact on water quality and crop production. Biological Forum-An International Journal, 2(2), 36-37.

Fenta, A., \& Kifle, A. (2014). Spatial Analysis of Groundwater Potential Using Remote Sensing and GIS-Based MultiCriteria Evaluation in Raya Valley, Nothern Ethiopia. Hydrogeology Journal, 23, 195-206.

Fetter, C. (2001). Applied Hydrogeology. New Jersey: Prentice-Hall, Inc,.

Gwalema, S. (2011). Impacts of urban development pressure on coastal local communities in Tanzania. The Indonesian Journal of Geography, 43(2), 123-140.

Lobo-Ferreira, J. P., Chachadi, A., Diamantino, C., \& Henriques, M. J. (2005). Assessing aquifer vulnerability to sea water intrusion using GALDIT Method: Part 1Application to the Portuguese Aquifer of Monte Gordo . The Fourth Inter-Celtic Colloquium in Hydrology and Management of Water Resources. Guimaraes, Portugal.

Marandi, A., \& Vallner, L. (2010). Upconingof saline water from the crystalline basement into the cambrian vendian aquifer system on The Kopli Peninsula, Northern Estonia. Estonian Journal of Earth Sciences, 59(4), 277-287.

Obikoya, I. B. (2010). Geohysical investigation ofthe fresh-saline water interface in the coastal area of Aberwyngregyn. MSc Thesis., School of Ocean Sciences, University of Wales, Bangor.
Pousa, J., Tosi, L., Kruse, E., Guaraglia, D., Bonardi, M., Mazzoldi, A., . . Schnack, E. (2007). Coastal processes and environmental hazards: the Buenos Aires (Argentina) and Venetian (Italy) Littorals. Environ. Geol, 51, 1307-1316.

Purnama, S. (1996). Perkembangan intrusi air laut di Kota Administratif Cilacap. Laporan Penelitian, Fakultas Geografi UGM, Yogyakarta.

Purnama, S., Febriarta, E., Cahyadi, A., Khakim, N., Ismangil, L., \& Prihatno, H. (2013). Identifikasi airtanah asin berdasar kanpendugaan geolistrik di pesisir Kota Cilacap Jawa Tengah. Geomedia :Jurnal Sains Geografi, 11(2), 183-190.

Rahmawati, N., Vullaume, J., \& Purnama, S. (2013). Salt intrusion in coastal and lowland areas of Semarang City. Journal of Hydrology, 494, 146-159.

Rotzoll, Kolja, Oki, S., D., El-Kadi, \& I., A. (2010). Changes of freshwater-lens thickness in basaltic Island aquifers overlain by thick coastal sediments. Hydrogeol. J, 18, 1425-1436.

Rushton, K. (2003). Groundwater Hydrology : Conceptual and Computational Models. The Atrium, Southern Gate, Chichester,West Sussex : John Wiley \& Sons Ltd.

Simoen, S., Darmanto, D., \& Darsomartoyo, S. (1977). A short note on a geoelectric survey in the Cilacap Area, Central Java. The Indonesian Journal of Geography, 7(34), 102114.

Tillman, F., \& Leake, S. (2010). Trends in groundwater levels in wells in the active management areas of Arizona, USA. Hydrogeol. J, 18, 1515-1524.

Todd, D., \& Mays, L. (2005). Groundwater Hydrology. New York: John Wiley \& Sons.

Waikar, M., \& Nilawar, A. (2014). Identification of Groundwater Potential Zone Using Remote Sensing and GIS Technique. International Journal of Innovative Research in Science Engineering and Technology, 3(5), 12163-12174.

Young Kim, K., Suk Park, Y., \& Pyo Kim, G. (2009). Dynamic freshwater-saline water interaction in the coastal zone of Jeju Island, South Korea. Hydrogeol. J, 17, 617-629. 